We gratefully acknowledge advice given by Professor C. E. Dent in the preparation of this paper.

\section{REFERENCES}

Albright F., Burnett, C. H., Parson, W., Reifenstein, E. C., and Roos, A. (1946). Medicine, 25, 399.

Albright, F., Butler, A. M., and Bloomberg, E. I. (1937). American fournal of Diseases of Children, 54, 529

Anderson, J. (1965). Fournal of Physiology, 130, 268.

Bijvoet, O. L. M., Morgan, D. B., and Fourman, P. (1969). Clinica Chemica Acta, 26, 15

Dent, C. E. (1952). Fournal of Bone and foint Surgery, 34B, 266.

Fanconi, G., and Girardet, P. (1952). Helvetica Paediatrica Acta, 7, 14.

Freeman, S., and Dunsky, I. (1950). American Fournal of Diseases of

Children, 79, 409.
Frame, B., Smith, R. W., jun., Fleming, J. L., and Manson, G. (1963). American fournal of Diseases of Children, 106, 147

Frame, B., Smith, R. W., and Wilson, E. W. (1961). Henry Ford Hospital Medical Bulletin, $9,548$.

Fraser, D., Jaco, N. T., Yendt, E. R., Munn, J. D., and Liu, E. (1957). American fournal of Diseases of Children, 93, 84

Fraser, D., et al. (1958). American fournal of Diseases of Children, 96, 460.

Holland, N. H., and West, C. D. (1962). Report of the Society for Paediatric Research, p. 117.

Jackson, W. P. U., Dowdle, E., and Linder, G. C. (1958). British Medical fournal, 1, 1269.
Lehnerdt, F. (1910). Beiträge zur pathologischen Anatomie und zur allgemeinen Pathologie, 47, 215

Lotz, M., Ney, R., and Bartter, F. C. (1964). Transactions of the Associations of American Physicians, 77, 281.

Mouriquand, G., Leulier, A., Bernheim, M., and Weill (1931). Presse Médicale, 39, 769.

Nagant de Deuxchaisnes, C., and Krane, S. M. (1965). Fournal of Clinical Investigation, 44, 1078.

Nassim, J. R., and Higgins, B. A. (1965). British Medical fournal, 1, 675 .

Nordin, B. E. C., and Smith, D. A. (1967). In L'Ostéomalacie, ed. D. J. Hioco, p. 379. Paris, Masson. Parfitt, A. M., Higgins, B. A., Nassim, J R., Collins, J. A., and Hilb,
A. (1964). Clinical Science, 27, 463.

Robertson, B. R., Harris, R. C., and McCune, D. J. (1942). American

fournal of Diseases of Children, 64, 948
Rominger, E., Meyer, H., and Bomskov, C. (1930). Zeitschrift für die gesamte experimentelle Medizin, 73, 343.

Rose, G. A. (1964). British Medical fournal, 2, 857.

Rose, G. A. (1964). British Medical fournal, 2, 857.
Waltner, K. (1927). Biochemische Zeitschrift, 188, 381.

West, C. D., Blanton, J. C., Silverman, F. N., and Holland, N. H. (1964). Fournal of Pediatrics, 64, 469.

Wilson, D. R., York, S. E., Jaworski, Z. F., and Yendt, E. R. (1965). Medicine, 44, 99.

Winters, R. W., Graham, J. B., Williams, T. F., McFalls, V. W., and Burnett, C. H. (1958). Medicine 37, 97.

Woolf, L. I. (1966). Renal Tubular Dysfunction, p. 100. Springfield, Illinois, Thomas.

\title{
Effect of Potassium Supplements on the Exchangeable Potassium in Chronic Heart Disease
}

\author{
R. J. WHITE,* M.B., M.R.C.P.
}

British Medical fournal, 1970, 3, 141-142

\begin{abstract}
Cummary: A study of the effect of additional oral potassium on the low body potassium of seven patients with severe valvular heart disease showed that the potassium supplements were retained. After one month's treatment the exchangeable potassium was significantly increased, but the predicted value was not reached in any of the patients. There was no significant change in plasma potassium. These results suggest that it is of benefit to increase the dose of oral potassium for at least one month preoperatively in patients undergoing cardiac surgery.
\end{abstract}

\section{Introduction}

Patients with severe heart disease are frequently depleted of potassium. It is often assumed that the intracellular potassium concentration is reduced, and that this may give rise to serious ill-effects such as cardiac arrhythmias. In some centres it is routine to increase the dose of oral potassium preoperatively with the intention of increasing the body potassium. The efficacy of this treatment in producing a rise in the cellular potassium is, however, not known. The effect of potassium supplements on the exchangeable potassium of patients with severe valvular heart disease has been studied. Since about $95 \%$ of the exchangeable potassium is intracellular, this measurement provides a good index of cellular potassium.

The findings suggest that the reduction of exchangeable potassium is at least partially corrected by oral potassium supplements, but a distinction cannot be made between an increase in intracellular potassium concentration and a movement of water together with potassium into the cells.

\section{Methods}

Seven patients with severe valvular heart disease were studied (Table I). They consented to the study after full explanation of the nature of the investigation and the procedures

*Medical Registrar, St. Bartholomew's Hospital, London E.C.1.
TABLE I.-Clinical Data

\begin{tabular}{|c|c|c|c|c|c|}
\hline Case No. & Age & Sex & $\begin{array}{c}\text { Height } \\
(\mathrm{cm} .)\end{array}$ & Diagnosis & Drug Therapy (Daily Dose) \\
\hline 1 & 27 & F. & 166 & M.V.D. & $\begin{array}{l}\text { Frusemide } 40 \mathrm{mg} \text {. Digoxin } 0.25 \mathrm{mg} . \\
\text { Slow-K } 600 \mathrm{mg} \text {. }\end{array}$ \\
\hline 2 & 50 & M. & 174 & A.V.D. & $\begin{array}{l}\text { Ethacrynic acid } 100 \mathrm{mg} \text {. Digoxin } 0.5 \\
\text { mg. Aldactone A } 100 \mathrm{mg} \text {. Slow-K } 1,800 \\
\mathrm{mg} \text {. }\end{array}$ \\
\hline $\begin{array}{l}3 \\
4\end{array}$ & $\begin{array}{l}24 \\
61\end{array}$ & F. & $\begin{array}{l}156 \\
159\end{array}$ & $\begin{array}{l}\text { A.V.D. } \\
\text { A.V.D. }\end{array}$ & $\begin{array}{l}\text { Navidrex K } 2 \text { tablets. Digoxin } 0.5 \mathrm{mg} \text {. } \\
\text { Frusemide } 40 \mathrm{mg} \text {. Digoxin } 0.25 \mathrm{mg} \text {. } \\
\text { Slow-K } 600 \mathrm{mg} \text {. }\end{array}$ \\
\hline 5 & 50 & F. & 152 & A.V.D. & $\begin{array}{l}\text { Bendrofluazide io mg. Digoxin } 0.25 \mathrm{mg} \text {. } \\
\text { Slow-K } 600 \mathrm{mg} \text {. }\end{array}$ \\
\hline $\begin{array}{l}6 \\
7\end{array}$ & $\begin{array}{l}42 \\
27\end{array}$ & $\begin{array}{l}\text { F. } \\
\text { F. }\end{array}$ & $\begin{array}{l}158 \\
160\end{array}$ & $\begin{array}{l}\text { M.V.D. } \\
\text { M.V.D. }\end{array}$ & $\begin{array}{l}\text { Digoxin } 0.25 \mathrm{mg} \text {. } \\
\text { Navidrex } \mathrm{K} \text { two tablets. Digoxin } 0.5 \mathrm{mg} .\end{array}$ \\
\hline
\end{tabular}

M.V.D. = Mitral valve disease. A.V.D. = Aortic valve disease.

involved. All except Case 6 had suffered from episodes of left ventricular or congestive heart failure, and were receiving diuretics together with potassium supplements. They were, however, free of oedema at the time of study and were being prepared for open-heart surgery. All were on digoxin.

The patients were given additional potassium in the form of Slow-K for one month. A daily supplement of $48 \mathrm{mEq}$ of potassium was attempted, but this dose was not given to Case 2 because the oral potassium dose was already large. This patient therefore received $24 \mathrm{mEq}$ daily. Case 4 was started on $48 \mathrm{mEq}$, but this was reduced the next day to $32 \mathrm{mEq}$ because of nausea. During the period of investigation the existing drug therapy was continued unchanged.

Measurements of plasma sodium and potassium and exchangeable potassium were made the day before oral potassium was increased, and were repeated after one month of treatment. Two measurements of total body water also were made in four of the patients. Exchangeable potassium was measured by isotope dilution, with ${ }^{42} \mathrm{~K} ; 100 \mu \mathrm{Ci}$ was injected intravenously and urine samples were collected 22-24 hours and 24-26 hours after the dose. The mean of the result from the two urine samples was taken. Normal values were predicted from the age, sex, and height of the patient, the regressions loge $\mathrm{K}^{\mathrm{e}}$ on loge height, derived by Flear et al. 
TABLE II.-Effect of Potassium Supplements

\begin{tabular}{|c|c|c|c|c|c|c|c|c|c|c|c|c|c|c|c|c|c|}
\hline \multirow{2}{*}{ Case No. } & \multirow{2}{*}{$\begin{array}{c}\text { Daily } \\
\text { Potassium } \\
\text { Supplement }\end{array}$} & \multicolumn{3}{|c|}{ Weight (kg.) } & \multicolumn{3}{|c|}{$\begin{array}{c}\text { Plasma Sodium } \\
\text { (mEq/1.) }\end{array}$} & \multicolumn{3}{|c|}{$\begin{array}{c}\text { Plasma Potassium } \\
\text { (mEq/1.) }\end{array}$} & \multicolumn{4}{|c|}{$\begin{array}{c}\text { Exchangeable Potassium } \\
\text { (mEq) }\end{array}$} & \multicolumn{3}{|c|}{ Total Body. Water } \\
\hline & & 1 & 2 & Change & 1 & 2 & Change & 1 & 2 & Change & Predicted & 1 & 2 & Change & 1 & 2 & Change \\
\hline $\begin{array}{l}1 \\
2 \\
3 \\
4 \\
5 \\
6 \\
7\end{array}$ & $\begin{array}{l}48 \mathrm{mEq} \\
24 \mathrm{mEq} \\
48 \mathrm{mEq} \\
32 \mathrm{mEq} \\
48 \mathrm{mEq} \\
48 \mathrm{mEq} \\
48 \mathrm{mEq}\end{array}$ & $\begin{array}{l}53.0 \\
57.8 \\
57.8 \\
53.4 \\
55.3 \\
63.2 \\
51.0\end{array}$ & $\begin{array}{l}54 \cdot 3 \\
58 \cdot 6 \\
58 \cdot 0 \\
52 \cdot 5 \\
52 \cdot 0 \\
64 \cdot 1 \\
51 \cdot 8\end{array}$ & $\begin{array}{l}+1.3 \\
+0.8 \\
+0.2 \\
-0.9 \\
-3.3 \\
+0.9 \\
+0.8\end{array}$ & $\begin{array}{l}134 \\
131 \\
135 \\
140 \\
139 \\
137 \\
134\end{array}$ & $\begin{array}{l}136 \\
136 \\
135 \\
139 \\
135 \\
138 \\
135 \\
\end{array}$ & $\begin{array}{r}+2 \\
+5 \\
0 \\
-1 \\
-4 \\
+1 \\
+1\end{array}$ & $\begin{array}{l}3.5 \\
4 \cdot 1 \\
3.7 \\
4 \cdot 2 \\
4.5 \\
4.8 \\
3.9 \\
\end{array}$ & $\begin{array}{l}3.9 \\
4.0 \\
3.6 \\
4.0 \\
4.2 \\
4.5 \\
3.7\end{array}$ & $\begin{array}{l}+0.4 \\
-0.1 \\
-0.1 \\
-0.2 \\
-0.3 \\
-0.3 \\
-0.2\end{array}$ & $\begin{array}{l}2,500 \\
2,870 \\
2,240 \\
2,660 \\
2,140 \\
3,580 \\
2,340\end{array}$ & $\begin{array}{l}2,080 \\
2,140 \\
1,790 \\
2,280 \\
1,720 \\
2,280 \\
1,500\end{array}$ & $\begin{array}{l}2,090 \\
2,310 \\
2,210 \\
2,380 \\
1,900 \\
2,420 \\
1,900\end{array}$ & $\begin{array}{l}+10 \\
+170 \\
+420 \\
+100 \\
+180 \\
+140 \\
+400\end{array}$ & $\begin{array}{l}28 \cdot 3 \\
31 \cdot 6 \\
26 \cdot 3 \\
\\
\\
24 \cdot 9\end{array}$ & $\begin{array}{l}29 \cdot 9 \\
34 \cdot 5 \\
26.0\end{array}$ & $\begin{array}{r}+1.6 \\
+2.9 \\
-0.3\end{array}$ \\
\hline $\begin{array}{l}\text { Eean ... } \\
\text { E.of mean } \\
\text { gnificance }\end{array}$ & $\ddot{x}$ & & & $\begin{array}{c}-0.286 \\
\pm 0.61 \\
\text { N.S. }\end{array}$ & & & $\begin{array}{l}+0.57 \\
\pm 1.04 \\
\text { N.S. }\end{array}$ & & & $\begin{array}{l}-0.11 \\
\pm 0.09 \\
\text { N.S. }\end{array}$ & \multicolumn{2}{|c|}{$P<0.05$} & & $\begin{array}{l}+200 \\
\pm 62 \cdot 8\end{array}$ & & & $\begin{array}{l}+1.97 \\
\pm 0.87 \\
\text { N.S. }\end{array}$ \\
\hline
\end{tabular}

*Supplements given as Slow-K. Each $600 \mathrm{mg}$. tablet contains $8 \mathrm{mEq} \mathrm{K}+$.

(1966) being used. Total body water was measured with tritium. After a 12-hour fast $500 \mu \mathrm{Ci}$ of tritiated water was administered orally and venous blood samples were taken at one and a half and two hours. The plasma was prepared for counting by distillation as previously described (White et al., 1969). Plasma sodium and potassium were measured by an E.E.L. flame photometer.

\section{Results}

The data for body weight, plasma sodium and potassium, exchangeable potassium $\left(\mathrm{K}^{\mathrm{e}}\right)$, and total body water are given in Table II together with the changes that occurred during the month of treatment. The predicted values for $\mathrm{K}^{\boldsymbol{\theta}}$ are also given.

Hyponatraemia was not a feature of these patients and no rise in plasma sodium was found. Neither, judging by body weight and total body water, was there a diuretic effect. There was a small but not significant increase in the total body water. No effect on the plasma potassium was seen.

The $\mathrm{K}^{\mathrm{e}}$ in all was significantly below the predicted value $(P<0.02)$. There was a mean increase of $200 \mathrm{mEq}$ after one month of treatment with additional oral potassium $(P<0.05)$, though the final value was still significantly lower than that predicted $(\mathrm{P}<0.05)$.

\section{Discussion}

The plasma potassium in patients with severe heart disease is usually within the normal range, but the exchangeable potassium is often low. Tissue-wasting probably plays a large part in this deficit, but there is some controversy as to the extent of any fall in the intracellular concentration of potassium. Theoretically a low intracellular concentration of potassium can be harmful in the myocardium because the reduction in membrane potential could result in increased excitability and the development of arrhythmias. The membrane potential is related to the logarithm of the ratio of intracellular to $\mathrm{Ki}$

extracellular potassium concentration ( $\mathrm{E} \alpha \log -)$, and a

lower membrane potential will facilitate depolarization in cells with spontaneous pacemaker activity.

Some workers maintain that the low exchangeable potassium reflects a fall in the intracellular potassium concentration (Flear et al., 1966), but in a previous study we concluded that no significant decrease in cellular concentration was present, except that a slight reduction might occur in the presence of hyponatraemia. Data were also presented to show that the potassium depletion was not related to the duration of diuretic therapy (White et al., 1969).

Previous studies of the effect of potassium in patients with heart failure have shown a rise in serum sodium when there is hyponatraemia before treatment (Flear and Cawley, 1962). When the serum sodium was above $132 \mathrm{mEq} /$ litre the increase was not significant. Laragh (1954) noted an increase in both serum sodium and potassium; Flear and Cawley (1962) found no rise in serum potassium but noted that fluctuations were more common after administration of potassium salts. Other workers have suggested that potassium has a diuretic effect. In one patient Cort and Matthews (1954) found clinical improvement with an increased urinary output and concluded that a large cellular deficit had been corrected. Our findings agree with those of Flear and Cawley (1962) in that no change in plasma potassium was found. None of our patients had serious hyponatraemia, and there was no significant increase in plasma sodium, though in one patient (Case 2) who had a plasma level of $131 \mathrm{mEq} / \mathrm{l}$. there was an increase of $5 \mathrm{mEq} / \mathrm{l}$.

There is little information to show if additional potassium is retained by the body. Brown et al. (1951) found that patients with heart disease have positive balance with orally administered potassium, but submitted that treatment with potassium was dangerous because of a tendency to cause a rise in the serum levels. Only one other similar study has been found in the literature. Nagant de Deuxchaisnes et al. (1961) gave potassium supplements to eight patients with heart disease, five of whom were oedematous, and concluded that the exchangeable potassium could not be corrected by this means. Examination of their data shows that the period of treatment was less than three weeks in seven of the patients and five were studied again after only one week. The exchangeable potassium increased in five of these patients, and these were those with the greatest potassium depletion. The present study shows a rise in exchangeable potassium in patients with potassium depletion, though during the month of treatment the predicted normal value was not reached in any of the patients. Since no change in plasma levels occurred, the potassium must have been retained within the cells. It is not possible to say, however, whether the cellular concentration of potassium was increased, because a concomitant entry of water into the cells cannot be excluded.

The results, therefore, indicate that additional oral potassium is retained by the body. It is likely to be of benefit to increase the potassium intake for at least one month preoperatively in patients awaiting valve replacement operations, because a rise in cellular potassium can be effected by this means.

This paper forms part of a thesis submitted for the degree of M.D. at Cambridge University. The study was made while I was in receipt of a grant from G. D. Searle \& Co. Ltd.

\section{REFERENCES}

Brown, H., Tanner, G. L. and Hecht, H. H. (1951). Fournal of Laboratory and Clinical Medicine 37, 506.

Cort, J. H., and Matthews, H. L. (1954). Lancet, 1, 1202.

Flear, C. T. G., and Cawley, R. H. (1962). British Heart fournal, 24 337.

Flear, C. T. G., Quinton, A., Carpenter, R. G., Domenet, J. G., and Sivyer, A. (1966). Clinica Chimica Acta, 13, 1

Laragh, J. H. (1954). Fournal of Clinical Investigation, 33, 807

Nagant de Deuxchaisnes, C., Collet, R. A., Busset, R., and Mach, R. S (1961). Lancet, 1, 681.

White, R. J., Chamberlain, D. A., Hamer, J., McAlister, J., and Hawkins, L. A. (1969). British Medical fourmal, 2, 606. 